\title{
Texture and trace element geochemistry of apatite in carbonatite related REE deposits: Fingerprinting magmatic- hydrothermal processes
}

\author{
LU, J. ${ }^{1}$, CHEN, W. ${ }^{1}$, YING, Y.C. ${ }^{1}$, JIANG, S.Y. ${ }^{1}$
}

${ }^{1}$ State Key Laboratory of Geological Processes and Mineral Resources, China University of Geosciences, Wuhan, China, 430074

Apatite is a ubiquitous accessory mineral in carbonatites, which incorporate a variety of trace elements including REEs. Textural and chemical variations of apatite from three carbonatite related REE deposits (Shaxiongdong, Miaoya and Bayan Obo) were investigated with the aim to trace the magmatic/hydrothermal processes.

Detailed cathodoluminescence (CL) and back-scatteredelectron (BSE) images of apatite reveal various textures, including (a) euhedral magmatic apatite with grain sizes of 100-300 $\mu \mathrm{m}$ usually showing inerratic zonation with CL yellow-greenish core and purplish rim; (b) euhedral to subhedral metasomatic apatite displaying turbid CL colour with monazite exsolution; (c) anhedral hydrothermal apatite in close association with fluorite, bastnaesite and barite that displays green CL colour or occuring as aggregates with lilac CL colour.

Magmatic apatite displays highest $\mathrm{Mn}$ and $\mathrm{Sr}$ contents (453 and $19110 \mathrm{ppm}$ in average) and is characterized by steep inclined REE chondrite noramlized pattern with average $\mathrm{La} / \mathrm{Yb}_{\mathrm{N}}$ and $\mathrm{La} / \mathrm{Sm}_{\mathrm{N}}$ values of 121 and 3.59. Of note, the purplish rim of magmatic apatite shows higher MREE contents (1147-1869 ppm) compared to that of the core (737$1000 \mathrm{ppm}$ ). Metasomatic apatite shows highly variable LREE patterns with $\mathrm{La} / \mathrm{Sm}_{\mathrm{N}}$ ratios varying from 0.13 to 5.80 , and the average $\mathrm{La} / \mathrm{Yb}_{\mathrm{N}}$ and $\mathrm{La} / \mathrm{Sm}_{\mathrm{N}}$ values (47.5 and 1.88) and $\mathrm{Mn}$ and Sr contents (275 and $10065 \mathrm{ppm}$ ) are lower compared to that for magmatic apatite. Hydrothermal apatite is characterized by slightly LREE depleted chondrite normalized REE patterns with average $\mathrm{La} / \mathrm{Yb}_{\mathrm{N}}$ and $\mathrm{La} / \mathrm{Sm}_{\mathrm{N}}$ ratios of 13.4 and 0.70 .

To sum up, the textural and compositional variations of apatite in the three deposits record various magmatic and hydrothermal processes, including 1) mineral fractionation for core-rim zoning in Shaxiongdong magmatic apatite; 2) dissolution-reprecipitation process for monazite exsolution in Miaoya and Bayan Obo metasomatic apatite; 3) co-deposition with fluorite, barite and bastnaesite from hydrothermal fluids for Bayan Obo hydrothermal apatite. 